the model sun are of such a length that when they disappear behind the disk, twilight is approximately ending. In addition to its daily motion, the sun is shown to move along a circle representing the ecliptic and it thus rises to the appropriate elevation at any time of year. Solar time may be read from this dial and Greenwich Mean Time is shown on a dial below. The equation of time may thus be obtained as the difference between the dials. The other side of the memorial carries an "Astral" dial. This shows the daily apparent motion of the northern circumpolar stars. Sidereal time may be read from this dial and it is also shown on dials on the "Zodiacal" side converted into degrees. The clock depicts events appropriate to the Iatitude and longitude of York, and is intended to give a picture of the heavens as seen by a navigator in an aircraft over the city. It is housed with a Book of Honour in a walnut frame designed by Prof. A. E. Richardson and ornamented by Mr. Maurice Lambert and Mr. H. J. Stammers.

\section{Atmospheric Pollution in Great Britain}

IN moving the second reading of the Clean Air Bill in the House of Commons on November 3, the parliamentary secretary to the Ministry of Housing and Local Government, Mr. W. F. Deedes, said that the Government believes that the necessary replacement in the black areas scheme of about 19 million tons of house coal by smokeless fuels cao be gradu. ally achieved over fifteen years. The Government has accepted the Beaver Committee's recommendations that the most efficient practicable method of removing sulphur should be used in power stations in or near populated areas, and research into this problem is being pressed forward. He emphasized that the rate of progress may be limited by the difficulty of finding the technical staff required by local authorities for the discharge of their additional responsibilities. Mr. Deedes announced the Government's acceptance of the Beaver Committee's recommendation for the establishment of a Clean Air Council, and in replying on the debate the Minister of Housing and Local Government said that it is the Government's intention to make the Bill as effective, tight and strong as possible consistent with what is practicable. He is prepared to consider the inclusion of a general introductory clause stating that clean air is a national policy, though he does not think it would add anything to the Bill, and also to make the appointed day, for the purpose of the seven-year period allowed for the modification of equipment, the day after the passing of the Bill. In regard to research, he emphasized the work already being carried out by the Department of Scientific and Industrial Research and referred to the construction by the Central Electricity Authority of a full-scale pilot plant for extensive trials at a power station. Mr. Sandys promised to consider sympathetically at a later stage any amendments likely to make the Bill a more effective instrument to eradicate a great social and economic evil, a menace to public health and a source of waste and destruction.

\section{Scientific Library Centre in London}

IN a written answer to questions from three members of the House of Commons on November 1, Mr. J. R. Bevins, parliamentary secretary to the Ministry of Works, as representing the Lord President of the Council, stated that the proposals for improved scientific libraries referred to in the eighth annual report of the Advisory Council on Scientific Policy are at present being considered by the Departments concerned. As these projects involve considerable capital expenditure, and the reference library scheme is bound up with wider questions affecting the Patent Office, Mr. Bevins regretted that he was not yet able to make a statement. In a further reply on November 8 , Mr. Bevins said that the capital cost of a new building to house both the Patent Office and its library, extended to provide a National Referenee Library, was estimated at rather more than $£ 2,000,000$.

\section{Economics of the Press in Great Britain}

THE broadsheet on the "Balance Sheet of the Press", issued earlier this year by Political and Economic Planning (Planning, 21, No. 384; 1955. Pp. $14 ; 2 s .6 d$.$) , is of particular interest in view of$ the recent announcement by the Board of Trade that control of newsprint in Great Britain is to end next year. The broadsheet directed attention to great changes which are impending in the organization of the British Press. It is the first of a series which sets out to examine these problems, and it throws some light on the critical reception of the Government's decision by the Newsprint Supply Company, which is desirous that some form of voluntary rationing should continue to safeguard the weaker papers, as the ending of control does not mean that supplies will then be adequate to meet demands. On this point the broadsheet suggests that the high price of newsprint is likely to prevent daily newspapers from reaching their pre-war size, although twelve-page papers are probable. A considerable rise in world demand is anticipated during the next decade, and substantially increased production is planned in spite of the fact that world supplies are severely limited in the immediate future; the provision of more news. print during the next fow years depends on renewed contracts with Canada, although, later, increased supplies may be available from non-dollar sources.

Between 1937 and 1947 the circulation of London and provincial dailies rose by more than ten million and that of Sunday newspapers by fourteen million, compared with an increase in population in the period of $2 \cdot 6$ million. Magazines and periodicals had a circulation of about twenty-six million in 1938 and probably more than forty million in 1952. Press advertising in 1954 was estimated at about $£ 160$ million out of a total advertising expenditure of $£ 280$ million, and, of this, 38 per cent was in provincial newspapers, 24 per cent in national newspapers, 21 per cent in magazines and periodicals and 16 per cent in trade and technical journals. The provincial nowspapers, posters and the smaller-circulation magazines are expected to lose most to television advertising. As regards the future, costs in all departments of newspaper production are expected to continue to rise, and the total circulation of the national papers is probably near its limit. Total sales revenue is unlikely to be increased by raising the price of the daily paper; unaccompanied by a larger paper, it could cause a substantial fall in sales. In view of competition from television advertising, substantial increases in advertising-rates are unlikely, nor, while papers remain at their present size, can the 33 per cent of their space devoted to advertising be increased. Much could be done, however, to eliminate waste of man-power and materials, and the broadsheet suggests that both management and labour should pay greater attention to the increase of efficiency in this way. 